\title{
Blended Learning for Chassis Maintenance and Light Vehicle Power Transfer Subject
}

\author{
Oktovianus Nau Lalian ${ }^{1, *}$, Eveline Siregar², Murni Winarsih ${ }^{3}$ \\ ${ }^{1,2,3}$ Education Technology, Universitas Negeri Jakarta, Jalan Rawamangun Muka, Jakarta, Indonesia \\ *Corresponding author: OktovianusNauLalian_9901817012@mhs.unj.ac.id
}

\begin{abstract}
The aimed of this study was to develop blended learning for Chassis Maintenance and Light Vehicle Power Transfer subject for second-grade students of light vehicle engineering major at Dewantara vocational school which is expected to help students and teacher in the learning process as a learning strategy to overcome the problem of lack of face-to-face time in class. The procedure for developing blended learning used the ADDIE model which is integrated with PEDATI at the instructional design stage. Data collection techniques are done by observation, interviews, and questionnaires. Data analysis techniques used qualitative and quantitative descriptive data analysis. Based on the results of the feasibility analysis from the material expert, the percentage of achievement level is $91.67 \%$ with a very good qualifications and appropriate to be used with revisions as needed, based on the results of the feasibility analysis from media expert, the percentage of achievement level is $80 \%$ with a good qualifications, and feasible to be used with revisions as needed, and based on the results of the feasibility analysis from the instructional design expert the percentage of achievement level is $96.47 \%$ with a very good qualifications, and feasible to use without any revisions. The development of blended learning will be very effective for the achievement of learning objectives optimally and efficiency in the use of learning time in class. This result implies that the blended learning is feasible to facilitate learning especially in limited learning time at school.
\end{abstract}

Keywords: blended learning; ADDIE; PEDATI

\section{Introduction}

Education is one of the most important factors in sustaining the continuity of life of the nation to the nation's dignity, sovereign and authoritative. Entering the 21 st-century education in Indonesia continues to change by the demands and developments in science and technology (Daryanto \& Karim, 2017). Indonesian education has moved according to the development of the times. Currently, it has entered the digital era in every learning activity. One of the demands the development of science and technology for the 21 st century of Indonesian education is the implementation of information and communication technology in learning. According to Mukarom \& Rusdiana (2016), the implementation of information and communication technologies in the learning activities are expected to change in the process of learning, where it becomes more effective, efficient, and enjoyable. The implementation of ICT in learning could improve the quality of learning and the ability of learners to communicate, collaborate, think critically, solve problems, and be creative (Fitriyadi, 2012).

The changes referred to in learning as a follow up of the implementation of ICT in learning that is expected to achieve optimal student learning outcomes, meaning by applying ICT, learning objectives can achieve effectively. Besides being effective towards achieving learning objectives, the application of ICT can also optimize learning time in class, so that 
the learning process will run efficiently. The implementation of ICT in learning will provide opportunities for students to explore more about their ability to assess a given problem, think critically about the given problem, and push the students to become more creative in learning. Therefore, the implementation of ICT must be done creatively and innovatively by teachers or instructors to develop and improve students' cognitive, affective, and psychomotor abilities.

According to Smaldino, Lowther, Mims, \& Russell (2015), the utilization of information and communication technology in learning activities today can be the use of media and the Internet are presented in the form of digital books, audio, video, computerbased learning, web-based learning (e-learning), computer-aided learning (CAI), multimediabased learning, presentation-based learning, and video conferencing (teleconferences). Today, various media as a result of ICT developments are available for students as learning resources. There are media by utilization as learning resources such as videos or animations that can be accessed through you-tube. There is also a medium that can be developed (by design) as a source of student learning such as e-modules, videos, PowerPoint presentations, and e-learning (Moodle, Edmodo). The media can enhance students learning outcomes and motivate students to participate in learning. Therefore, teachers or instructors in the industrial era 4.0 are required to have sufficient abilities in designing a variety of more innovative learning media to create quality learning.

One of the educational institutions in Indonesia, which certainly should apply information and communication technologies in the learning activity is vocational high school. In this industrial era 4.0, existing resources both technological and human resources in vocational high schools are optimal for implementing ICT in learning activities although there are still limitations or obstacles caused by lack of technology facilities or the unavailability of competent human resources in ICT (Husain, 2014).

Vocational high school prepares its students to have skills or competence in a particular field of expertise, such as automotive, construction, hospitality, tourism, catering, computer engineering, and so forth. The implementation of ICT in learning activities in vocational high school has been integrating into subjects are taught. However, the implementation of ICT in some vocational high schools is not optimal because of the uneven availability of ICT facilities for each vocational school and the teachers' unpreparedness towards the development of ICT in learning. Therefore, it is necessary to support ICT facilities for each vocational high school and training programs for teachers to have the skills to apply ICT in learning. 
One of the uses of ICT in the industrial era 4.0 that is suitable to be applied for vocational students is blended learning. According to Akkoyunlu \& Soylu (2008), Garrison \& Vaughan (2017), and Graham, Borup, Short, \& Archambault (2019), blended learning is a strategic combination of online and face-to-face learning. Graham et al (2019) make a general definition of primary and secondary education (K-12) adding that in this combination should give students some control over time, place, path, and/or speed. This means that learning time is no longer limited to school days, the place of learning is no longer limited in the class, the learning path is no longer limited to the pedagogy used by the teacher. Then it can be synthesized that blended learning is the right combination of face-to-face strategy and online learning to create an optimum learning experience so that it can achieve predetermined learning outcomes.

The blended learning process is carried out according to the schedule that the subject teacher has made for face to face and online learning. Face to face learning allows students to discuss and exchange information with the teacher and between students directly at the same time and place (Miliszewska, 2017). While, online learning can be accessed flexibly anywhere and anytime that allows students to determine the time and place in learning (Cole \& Kritzer, 2009; Utami, 2018)

There are three basic components of online learning according to Dabbagh \& Bannan-Ritland (2005), (1) learning strategies are plans and techniques that will be carried out by instructors or teachers in facilitating student to learn, such as: collaborative learning, independent learning, articulation, games / games, roles, reflection, exploration, and problem solving; (2) online learning technology is a device used to channel learning materials online and can implement learning strategies, such as: asynchronous and synchronous, communication devices, hypermedia and multimedia, web, course management system (CMS), and learning management system (LMS); (3) pedagogical models are cognitive models or theoretical constructs derived from learning theories that can implement instructional specifications and learning strategies, such as: open, flexible, distributed education, asynchronous learning networks, virtual learning environments, situated learning, communities of practice, knowledge-building communities.

Even though the technological resources are adequate and the human resources of both teachers and students of vocational schools able to use existing technology, but learning that occurs in the classroom is not optimal. It happens because some vocational schools in the Java area are still under one-roof with other schools, so the learning time in class is not optimal, especially for vocational subjects. Thus, to overcome this problem it is necessary to 
develop a learning media in teaching, where the media to be developed is adapted to the needs of students and can be learned anywhere by utilizing technological resources around the students.

Dewantara vocational school is one of the one-roof school models in Java, especially in Cikarang, West Java Province. Learning that takes place at the school is only scheduled for 5 hours per week for all subjects. So there are many shortages of learning time for vocational subjects in class. Even the school already has adequate by technological resources, but the existing technology resources have not been optimally applied in learning activities to overcome the problem of lack of learning time in the classroom.

Therefore, to overcome the problem of lack of learning time at school, it is necessary to develop a learning strategy that able to overcome this gap by utilizing the availability of technology resources at Dewantara vocational school. The development of learning strategies will be held for the light vehicle engineering expertise program and taking one of the vocational subjects to be developed as student learning material for blended learning. Expected results of this blended learning strategy, besides, to overcome the lack of face-toface time in class, will be also a source of learning for students. The online material can be accessed anytime and anywhere. The blended learning strategy is also expected to enhance students learning outcomes.

Cognitive subject matter such as understanding, conceptual, and procedures of the chassis maintenance and light vehicle power transfer subject will be studied online by students. While the material that is a skill or practice (psychomotor) will be studied face-toface in the classroom or practical workshop by supervision from subject teachers. According to Darmawan (2015), learning with a blended strategy can streamline time and can do the learning process with more time portions.

State of the art in this research is the blended learning will be developed by combining precisely and systematically face-to-face and online learning strategies to create students learning experiences, so students learning outcomes will also be directly proportional to this. The blended learning strategy applied is used to map and organize faceto-face learning materials in the classroom and online learning materials that students can learn outside the classroom. It is expected that by implementing a systematic learning strategy, the use of technology, and appropriate pedagogical models in learning will be more optimal in achieving learning objectives and in making efficient limited face-to-face time in class. 


\section{Materials and Methods}

This research is a type of research and development (R\&D). Research and development is a systematic method or process in designing, developing, validating, and evaluating a product used in learning or non-learning. The intended products such as textbooks, learning videos, computer software, methods, and learning or training programs. In this study, the researcher will develop learning products of blended learning for chassis maintenance and light vehicle power transfer subject for second-grade students of light vehicle engineering at Dewantara vocational school.

To develop blended learning products, researcher use the ADDIE model integrated with the PEDATI model which comes from a local acronym (PElajari/learn, DAlami/comprehend, Terapkan/apply, dan evaluasI/evaluation) as a reference in developing blended learning. The ADDIE model consists of five stages, (1) Analyse, (2) Design, (3) Development, (4) Implementation, and (5) Evaluation. While the PEDATI model consists of five stages as well, they are (1) Formulating learning achievements/objectives, (2) Mapping and organizing learning material, (3) Selecting and determining synchronous and asynchronous learning activities, (4) Designing asynchronous learning activities, and ( 5) Designing synchronous learning activities.

Data collection techniques were carried out through observation, interviews with the subject teacher of chassis maintenance and light vehicle power transfer, and head of light vehicle engineering expertise program, as well as through questionnaires given to students of second-grade of the light vehicle engineering program. The blended learning development research instruments used to collect data are gap analysis instrument, the needs, and students characteristic instrument, as well as the instruments used in developing by experts from aspects of the material, instructional design, and media, and instruments for students as respondents.

Data analysis techniques used in this research are (1) qualitative descriptive analysis technique, this analysis used to manage the results of data review from material experts, learning design experts, instructional media experts, and the result of students respondent. This data analysis technique is done by grouping information from qualitative data such as comments, suggestions, criticisms of improvements, or revisions contained in the questionnaire; and (2) a quantitative descriptive analysis technique used to process the data obtained in the form of a percentage. The formula used to calculate the percentage of each test subject is a percentage $(\%)=\frac{\sum x}{S M I} X 100 \%$, where $\sum x$ is the total of the score, and SMI 
is the ideal maximum of the score (Tegeh et al., 2014). Decision making on the development of blended learning uses the provisions shown in table 1.

Table 1. Conversion Rate of Achievement Review Results

\begin{tabular}{lll}
\hline Level of Achievement & Qualification & Description \\
\hline $90 \%-100 \%$ & Very good & No need to revise \\
$75 \%-89 \%$ & Good & Revised as needed \\
$65 \%-74 \%$ & Enough & Quite a lot of revisions \\
$55 \%-64 \%$ & Not good enough & Much revised \\
$0 \quad-54 \%$ & Very bad & revised total \\
\hline
\end{tabular}

Flowchart of the development of blended learning of chassis maintenance and light vehicle power transfer subject with the ADDIE model integrated with the PEDATI model is shown in figure 1 below:

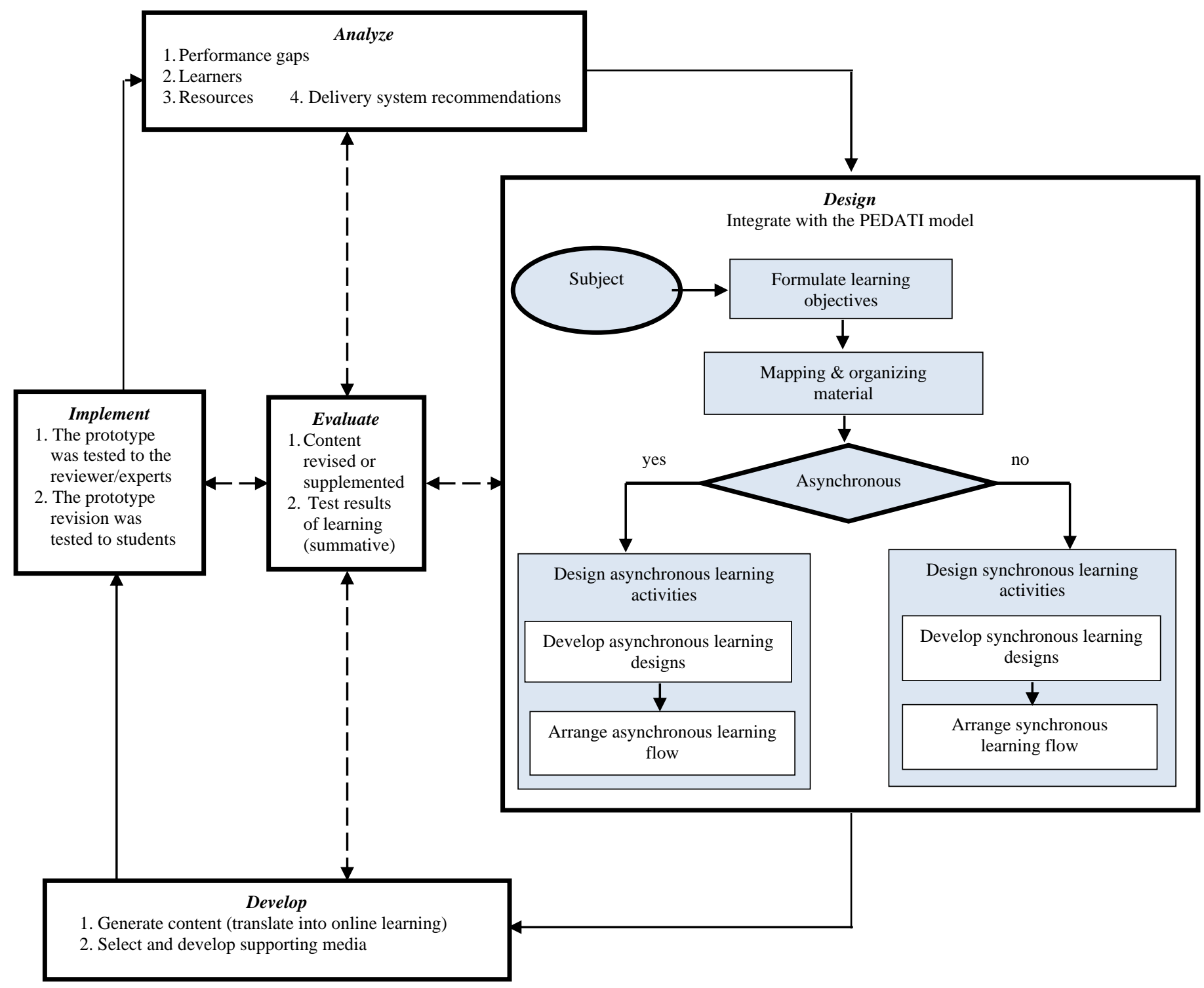

Figure 1. Flowchart of Blended Learning Development 


\section{Results and Discussion}

Blended learning development for chassis maintenance and light vehicle power transfer applying the flipped classroom model. With the flipped classroom model, cognitive materials, such as understanding, conceptual, and procedural/work methods are studied online outside the classroom through online text media, online PowerPoint, infographics, animation, or video (Butt, 2014; Mohanty \& Parida, 2016; Wallace, 2014). According to Milman (2012), three types of knowledge can be given to learning with the flipped classroom model, which is factual, conceptual, and metacognitive. Thus the factual, conceptual, and metacognitive type of knowledge of chassis maintenance and light vehicle power transfer materials will be studied online by students through network-based learning media. Whereas for the skills materials are practiced in class or practice workshop. The composition of the blended learning of chassis maintenance and light vehicle power transfer consists of $25 \%$ online material and $75 \%$ practice material in class or practice workshop. This composition based on the gap analysis occurs in the learning. According to Prasetyo, Putro, \& Wirawan (2016), the composition of blended learning for vocational students is 50 Face to Face /50 online, 75 Face to Face /25 online, and 25 Face to Face /75 online.

Blended learning with the flipped classroom model is regularly scheduled by the subject teacher, when to have face-to-face learning in class and when to have online learning. Online learning is given to students twice a week. Staker \& Horn (2012) classifies the flipped classroom model as a rotation model because it is a learning model that requires students to rotate within the schedule set by the teacher among learning modalities, at least one of them is online learning. The flipped classroom was chosen as a model in the development of blended learning in the subject of chassis maintenance and light vehicle power transfer because there is a balance between the combination of activities carried out by students in the classroom and learning activities carried out outside the classroom. Through the flipped classroom model of which should be delivered by the teacher, learned online by students through a particular medium, so that in the class will be a more active learning process.

The process of developing blended learning for chassis maintenance and light vehicle power transfer subject follows the ADDIE model procedure which integrated with the PEDATI model at the instructional design stage. ADDIE and PEDATI models are development models oriented to learning products. According to Branch \& Dousay (2015), the product-oriented development model focused on creating learning products used for selfdirected learning. 
Blended learning prototypes have been reviewed by a material expert, media expert, and instructional design expert before trying and implemented to students. The reviewers' trials are aimed in assessing the feasibility of blended learning products from material aspects by a material expert, instructional design aspects by an instructional design expert, and media aspects by a media expert.

The following are the results of the feasibility trials from the material expert, media expert, and instructional design expert are shown in table 2, 3 and 4.

a. The results of the eligibility of material experts

Table 2. The Eligibility Results of Material Expert

\begin{tabular}{|c|c|c|}
\hline Aspect & Indicator & Score \\
\hline \multirow[t]{7}{*}{ Learning } & $\begin{array}{l}\text { 1. The suitability of the formulation of learning } \\
\text { objectives }\end{array}$ & 5 \\
\hline & $\begin{array}{l}\text { 2. The suitability of the method used with the learning } \\
\text { objectives }\end{array}$ & 5 \\
\hline & $\begin{array}{l}\text { 3. The suitability of the task or exercise provided with } \\
\text { the learning objectives }\end{array}$ & 4 \\
\hline & $\begin{array}{l}\text { 4. The suitability of the description of the material with } \\
\text { the learning objectives }\end{array}$ & 5 \\
\hline & $\begin{array}{l}\text { 5. The description of the material presented in the } \\
\text { learning is easily understood by students }\end{array}$ & 4 \\
\hline & $\begin{array}{l}\text { 6. Clarity conclusion or summary of which is presented } \\
\text { in the learning }\end{array}$ & 4 \\
\hline & 7. Completeness of evaluation presented in learning & 4 \\
\hline \multirow[t]{11}{*}{ Material } & $\begin{array}{l}\text { 8. The relevance of the material presented to the learning } \\
\text { objectives }\end{array}$ & 5 \\
\hline & $\begin{array}{l}\text { 9. The depth of the material can achieve the learning } \\
\text { objectives }\end{array}$ & 5 \\
\hline & $\begin{array}{l}\text { 10. The accuracy of the material presented to achieve the } \\
\text { learning objectives }\end{array}$ & 5 \\
\hline & $\begin{array}{l}\text { 11. Description of the material presented can add insight } \\
\text { to students }\end{array}$ & 4 \\
\hline & 12. Suitability of the example with the material & 4 \\
\hline & $\begin{array}{l}\text { 13. The suitability of the material with the characteristics } \\
\text { of students }\end{array}$ & 5 \\
\hline & $\begin{array}{l}\text { 14. The suitability of the practice questions with the } \\
\text { learning objectives }\end{array}$ & 5 \\
\hline & $\begin{array}{l}\text { 15. Completeness learning components provided in the } \\
\text { learning material }\end{array}$ & 5 \\
\hline & $\begin{array}{l}\text { 16. The adequacy of the material to achieve the learning } \\
\text { objectives }\end{array}$ & 4 \\
\hline & $\begin{array}{l}\text { 17. Recency of the material presented in the network- } \\
\text { based learning }\end{array}$ & 5 \\
\hline & $\begin{array}{l}\text { 18. References used in network-based learning media are } \\
\text { adequate }\end{array}$ & 4 \\
\hline $\begin{array}{l}\text { Language and } \\
\text { Communicatio }\end{array}$ & $\begin{array}{l}\text { 19. Conformity of spelling used in network-based learning } \\
\text { material with EYD rules }\end{array}$ & 5 \\
\hline
\end{tabular}


$\mathrm{n}$
20. The accuracy of the use of language in network-based 5 learning materials

21. Suitability of language style used by students 5

4 examples on network-based learning materials

23. Ease editorial on network-based learning materials 4

24. Clarity of readability of network-based learning 5 material

5 4

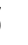

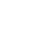

Based on the results of the assessment of the feasibility of the learning material expert in table 2 above, the percentage of the achievement level of the material expert judgment is 91.67\%. The results of the analysis of the material aspects by a material expert, after being converted to the conversion table in table 1 , the percentage of achievement level in very good qualifications, and is worthy of use with revisions as needed in the learning aspects and material aspects. Learning aspects with an average percentage of $85.71 \%$ are in good qualifications, material aspects with an average percentage of $92.73 \%$ are in very good qualifications, and language and communication aspects with an average percentage of $96.67 \%$ are in very good qualifications. According to the material expert, the material presented in the network-based learning media is in accordance with the learning objectives and the scope of the material needs to be added to achieve the ultimate goal of learning.

b. The results of the eligibility of media experts

Table 3. The Eligibility Results of Media Expert

\begin{tabular}{|c|c|c|}
\hline Aspect & Indicator & Score \\
\hline \multirow[t]{7}{*}{ Media Display } & $\begin{array}{l}\text { 1. Display the layout of learning materials in } \\
\text { network-based learning media }\end{array}$ & 4 \\
\hline & $\begin{array}{l}\text { 2. Harmony of color in the background, header, } \\
\text { and other components }\end{array}$ & 3 \\
\hline & $\begin{array}{l}\text { 3. The harmony of the composition of the colors } \\
\text { used }\end{array}$ & 4 \\
\hline & $\begin{array}{l}\text { 4. The attractiveness of the display graphics such } \\
\text { as layout, color and typography }\end{array}$ & 4 \\
\hline & $\begin{array}{l}\text { 5. Carrying capacity of the graphic to the content, } \\
\text { structure and navigation }\end{array}$ & 4 \\
\hline & $\begin{array}{l}\text { 6. The relevance of graphics used with the theme } \\
\text { of network-based learning media }\end{array}$ & 4 \\
\hline & $\begin{array}{l}\text { 7. Ease of using navigation on network-based } \\
\text { learning media }\end{array}$ & 5 \\
\hline $\begin{array}{l}\text { Program/ } \\
\text { Compatibility }\end{array}$ & $\begin{array}{l}\text { 8. Ease in understanding the instructions provided } \\
\text { in the use of network-based learning media }\end{array}$ & 4 \\
\hline
\end{tabular}


Presentation of Materials and Media
9. Ease of accessing navigation in the media and between media, as well as accessing web components

10. Ease in finding the desired data or materials 4

11. Speed of loading media capacity 4

12. Completeness of tools in meeting learning 5 needs

13. Suitability of features or functions available on 4 network-based learning media with the browser used

14. The accuracy of the use of hyperlinks on web- 4 based learning media

15. Availability of question features to overcome 3 student difficulties

16. Availability of feedback features to help 4 students

17. Availability of chat and forum features that can 4 be utilized by students

18. The level of upload speed and download 4 content

19. The attractiveness of learning materials displayed on network-based learning media for students

20. Neatness of learning material presented on network-based learning media

21. The level of text readability in network-based 4 learning media

22. The accuracy of the font types used in network- 4 based learning media

23. Harmony in the use of color combinations for 4 text

24 . The contrast of text and background color

25 . The accuracy of the icons used in networkbased learning media

26. Video quality contained in network-based 4 learning media

27. Suitability of other media used in network- 4 based learning

28. The media are independent and can be used for 4 online learning

\section{Total} 112

Based on the results of the assessment of the feasibility of the media expert in table 3 above, the percentage of the achievement level of the media expert judgment is $80 \%$. The results of the analysis of the media aspects by a media expert, after being converted to the conversion table in table 1 , the percentage of achievement level in good qualifications, and feasible to use with revisions as needed on aspects of media appearance, aspects of 
program/compatibility, and aspects of the presentation of material and media. The aspects of media display with an average percentage of $80 \%$ are in good qualifications, aspects of the program/compatibility with an average percentage of $80 \%$ are in good qualifications, and aspects of the presentation of materials and media with an average percentage of $80 \%$ are in good qualifications. According to media expert, use contextual illustrations in the header, use communicative language, pay attention to learning principles, increase learning activities, and optimize assignments.

c. The results of the eligibility of instructional design experts

Table 4. The Eligibility Results of Instructional Design Expert

\begin{tabular}{|c|c|c|}
\hline Aspect & Indicator & Score \\
\hline \multirow[t]{9}{*}{ Learning } & $\begin{array}{l}\text { 1. Clarity of the formulation of learning } \\
\text { objectives }\end{array}$ & 5 \\
\hline & $\begin{array}{l}\text { 2. Completeness brief explanation in the } \\
\text { introduction }\end{array}$ & 5 \\
\hline & $\begin{array}{l}\text { 3. The suitability of the method used with the } \\
\text { learning objectives }\end{array}$ & 5 \\
\hline & $\begin{array}{l}\text { 4. Suitability of the task or exercise provided with } \\
\text { the learning objectives }\end{array}$ & 5 \\
\hline & $\begin{array}{l}\text { 5. The suitability of the description of the } \\
\text { material with the learning objectives }\end{array}$ & 5 \\
\hline & $\begin{array}{l}\text { 6. The suitability of the material sequence to } \\
\text { achieve learning objectives }\end{array}$ & 5 \\
\hline & $\begin{array}{l}\text { 7. Clarity of conclusions or summaries presented } \\
\text { in network-based learning }\end{array}$ & 5 \\
\hline & $\begin{array}{l}\text { 8. Completeness of evaluation presented in } \\
\text { network based learning }\end{array}$ & 5 \\
\hline & $\begin{array}{l}\text { 9. The time needed to explore the material is } \\
\text { ideal }\end{array}$ & 5 \\
\hline \multirow[t]{2}{*}{ Display } & $\begin{array}{l}\text { 10. The ability of the media to provide motivation } \\
\text { for students }\end{array}$ & 5 \\
\hline & $\begin{array}{l}\text { 11. Suitability of network-based learning media } \\
\text { with student characteristics }\end{array}$ & 5 \\
\hline \multirow[t]{6}{*}{$\begin{array}{l}\text { Language and } \\
\text { Communication }\end{array}$} & $\begin{array}{l}\text { 12. Conformity of spelling in media-based learning } \\
\text { media with EYD rules }\end{array}$ & 5 \\
\hline & $\begin{array}{l}\text { 13. Clarity of the editorial on network-based } \\
\text { learning media }\end{array}$ & 5 \\
\hline & $\begin{array}{l}\text { 14. The accuracy of the use of examples and non- } \\
\text { examples on network-based learning media }\end{array}$ & 5 \\
\hline & $\begin{array}{l}\text { 15. Accuracy of language use in media-based } \\
\text { learning network }\end{array}$ & 4 \\
\hline & 16. Suitability of language style used by students & 4 \\
\hline & $\begin{array}{l}\text { 17. Clarity of the level of readability in network- } \\
\text { based learning media }\end{array}$ & 4 \\
\hline Total & & 82 \\
\hline
\end{tabular}


Based on the results of the assessment of the feasibility of the instructional design expert in table 4 above, the percentage of the achievement level of the instructional design expert judgment is $96.47 \%$. After being converted to the conversion table in table 1 , the percentage of achievement level in a very good qualifications, and is suitable for use without any revision of the learning aspects, display aspects, as well as language and communication aspects. The results of the assessment of the percentage of learning aspects with an average percentage of $100 \%$ are in very good qualifications, aspects of appearance with an average percentage of $100 \%$ are in very good qualifications, and aspects of language and communication with an average percentage of $90 \%$ are in very good qualifications. According to instructional design expert, the model used is appropriate and appears to be effective and efficient in achieving learning objectives. Thus, based on the results of a feasibility review from the material expert, media expert, and instructional design expert the development of blended learning feasible and can be used in learning activities and effective to achieve the optimal learning objectives and efficiency in using the learning time at school.

Some researches are relevant to the development of blended learning for vocational students of which has been done by (1) Banggur, Situmorang, \& Rusmono (2018), about the development of blended learning in multimedia etymology subjects. This study used the Dick and Carey model with Edmodo (learning management system) as a media platform. Delivery strategies of face-to-face learning were $70 \%$ for learning skills or practice and $30 \%$ online material for cognitive material. The results of the study found that the development of blended learning in multimedia etymology subject is good and proper to use, can motivate students to learn independently, and can effectively improve student learning outcomes even though the achievement of learning outcomes has not been maximized; (2) Development of blended learning model in KKPI subject for class XI at SMK Negeri 2 Purwodadi by Kurniawati \& Wardi (2014). The development of blended learning in this study used the ADDIE model as a reference for the development model. Learning technology that is used as a platform in this research is efront version 3.6.12. The strategy used in implementing blended learning in this study was to combine face-to-face with a portion of $56.57 \%$ and online learning with a portion of $43.33 \%$. The results of the study found that the development of the blended learning model in KKPI subjects effective for the learning outcomes and encourage students motivation; (3) Aeni, Prihatin, \& Utanto (2017), conducted the research about the development of blended learning model with problem-based learning in computer systems subject. The design of this study used 10 stages which are simplified into three 
stages, namely the preliminary, development, and product testing stages with Edmodo (learning management system) as a media platform. The strategy used in implementing blended learning in this research is combining blended learning with problem-based learning. The results found that the blended learning development model with problem-based learning is feasible to use in learning and is effective in improving student learning outcomes in class X Multimedia SMK Negeri 8 Semarang; and (4) Estika (2017), researched the development of blended learning with flipped classroom strategies in multimedia design subject at SMK PGRI Ploso. This research design used a quasi-experimental with a non-equivalent control group design using video with HDV (high definition video) format. The strategy used in implementing blended learning in this study is the flipped classroom. The results of the study found significant effects on the development of blended learning with a flipped classroom strategy to improve student learning outcomes in multimedia design subject at SMK PGRI Ploso.

The results of previous studies found that the development of blended learning is an innovation in learning as a reference/learning resource for students, can motivate students in learning and for effectiveness in learning, and increase learning outcomes optimally. This study had the same goals as previous studies are effective in achieving learning objectives optimally. Besides being effective towards learning outcomes, it is also efficient in using learning time at school. Flipped classroom helps teachers work in allocating available learning time efficiently in schools so that teachers can strengthen or focus on the topic of the lesson or skills from the knowledge given to students in the class (Arnold-Garza, 2014; Mccarthy, 2016; Ozdamli \& Asiksoy, 2016; Trilaksono et al., 2018).

The novelty of this research is using the ADDIE model integrated with the PEDATI model at the design stage as a reference model in blended learning development. The learning technology is Moodle version 3.8.1. The instructional strategy used collaboration and selfdirected learning. While the pedagogical model used a virtual learning environment. The results of this study are expected to be very effective and efficient in the learning process for Dewantara vocational school students both towards learning outcomes optimally and efficiently in managing limited learning time in class. The development of blended learning is also a source of learning for students.

Next is the display of the development of blended learning of chassis maintaining and light vehicle power transfer for students. First, users/students must log in by filling in their username and password to get access as a student. The username and password are given by 
the e-learning administrator to the users/students. The form to login to the e-learning portal can be seen in the image below:

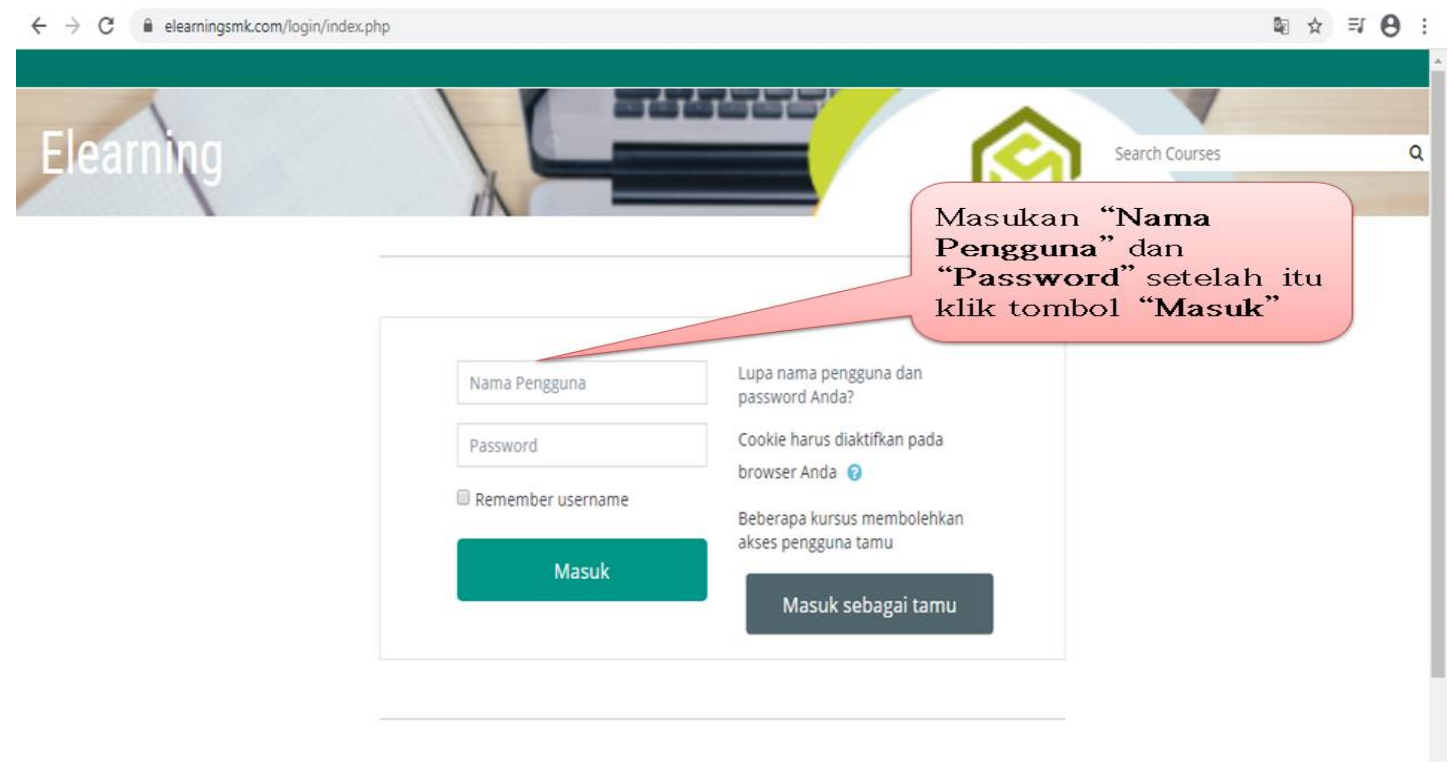

Figure 2. Login Form

And after login, user / student will go on display subjects that opened for students like the image below:

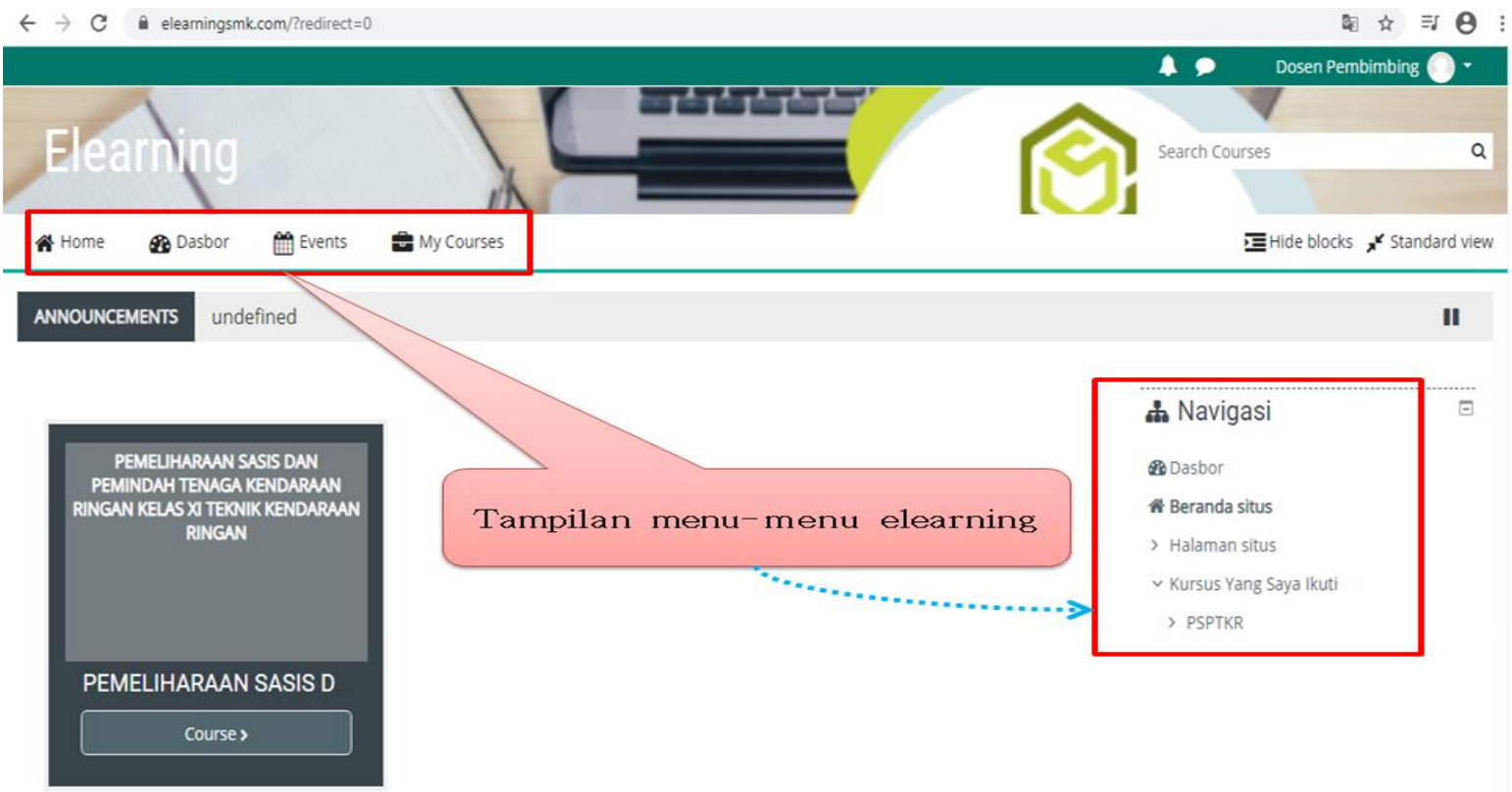

Figure 3. Display the homepage and e-learning menus

After clicking the menu on the subject title, a subject description, guidelines, and materials or topics will be displayed per meeting according to the online learning time that has been designed by teacher. 


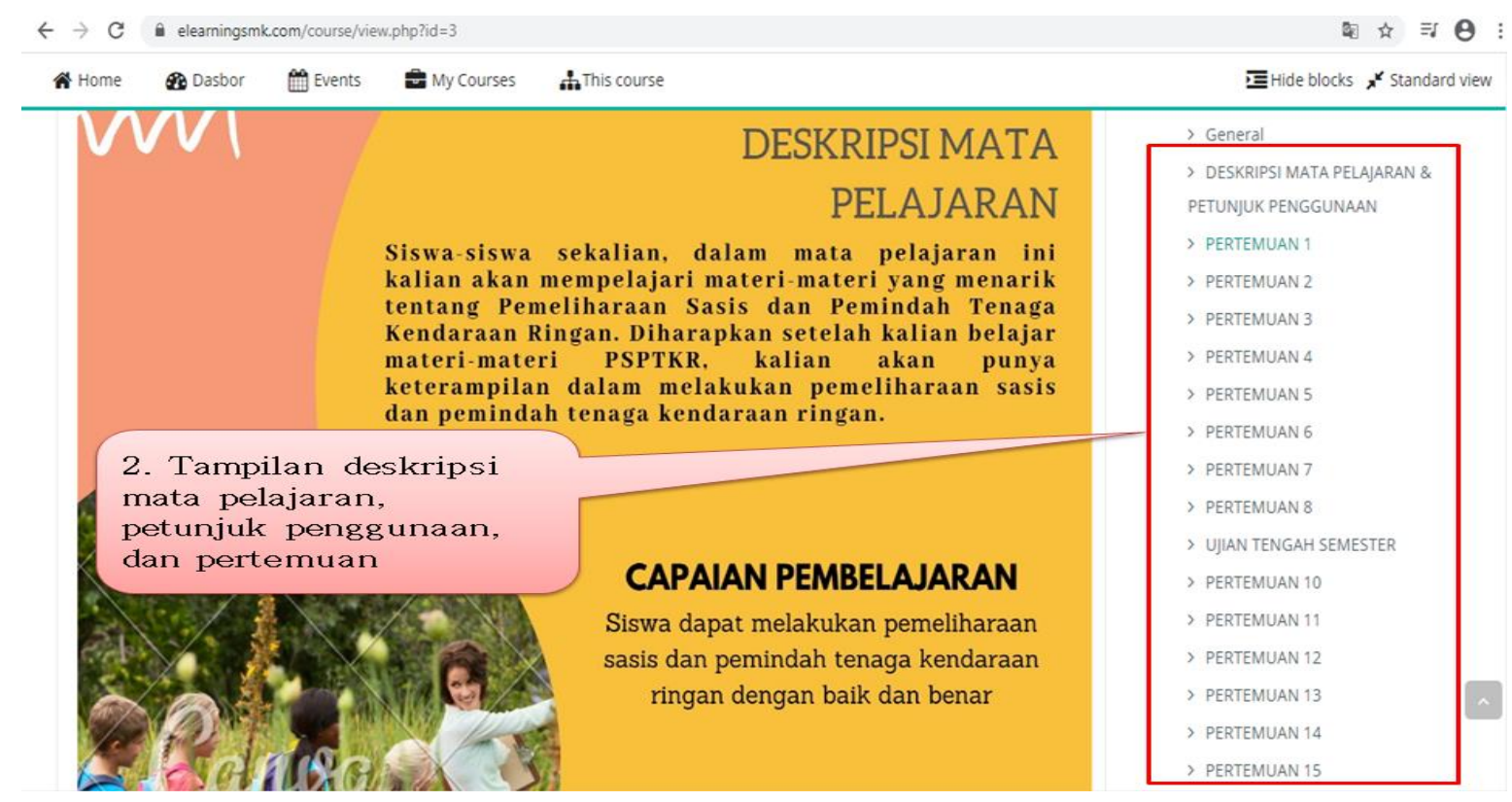

Figure 4. Display description of subjects, guidlines, and meetings

Then, click the meeting was opened, a meeting menu will appear containing a description of the topic or material to be studied.

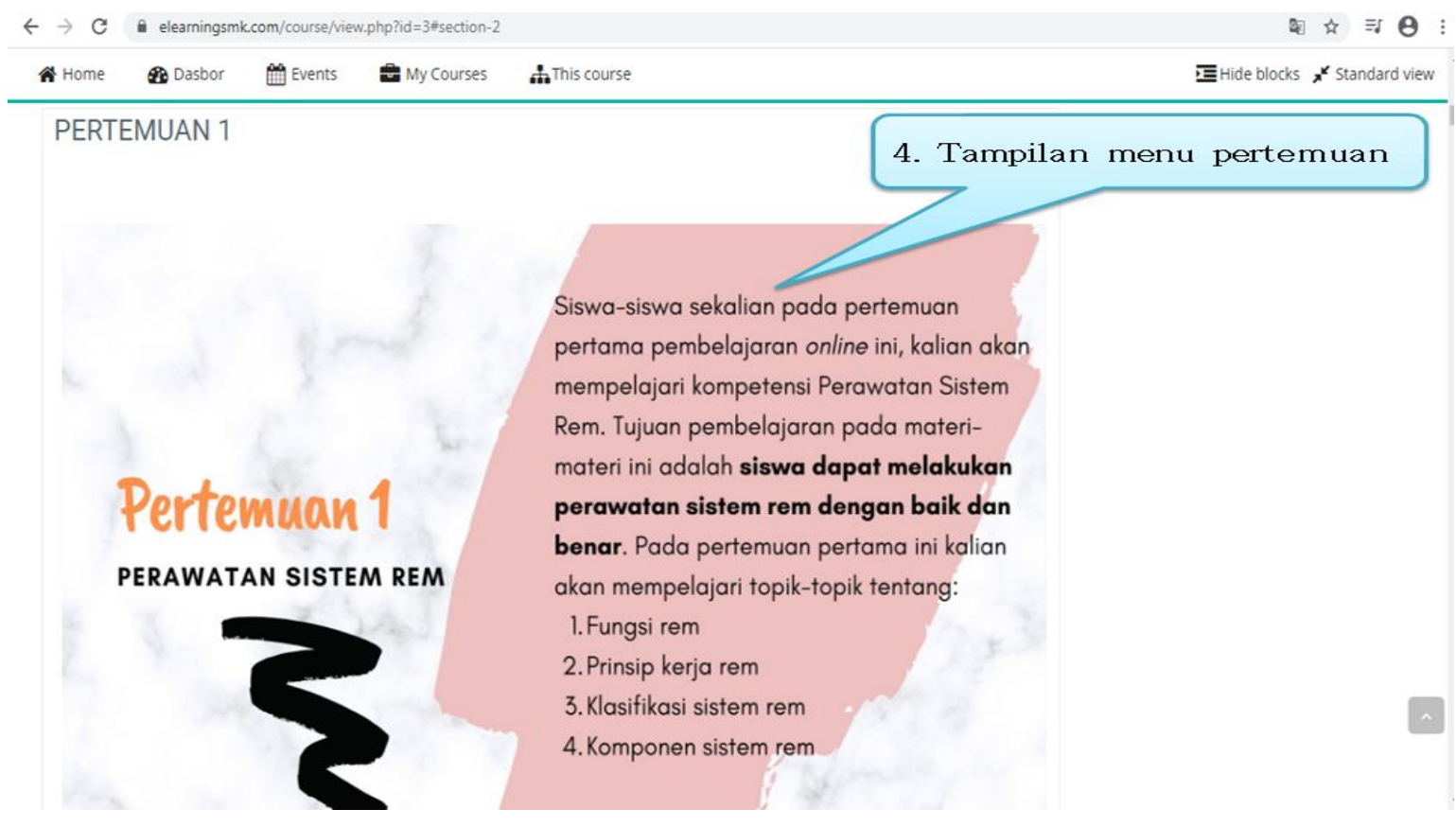

Figure 5. Display the meeting menu

After that, at the bottom of the meeting menu will display the topic/material displayed at that time. The subject matter is distributed in the form of online text, document files (*. Doc), pdf files (*. Pdf), presentation files (*. PPT), slide shares, infographics, videos, or animations. How to view and download materials, follow the steps below. 


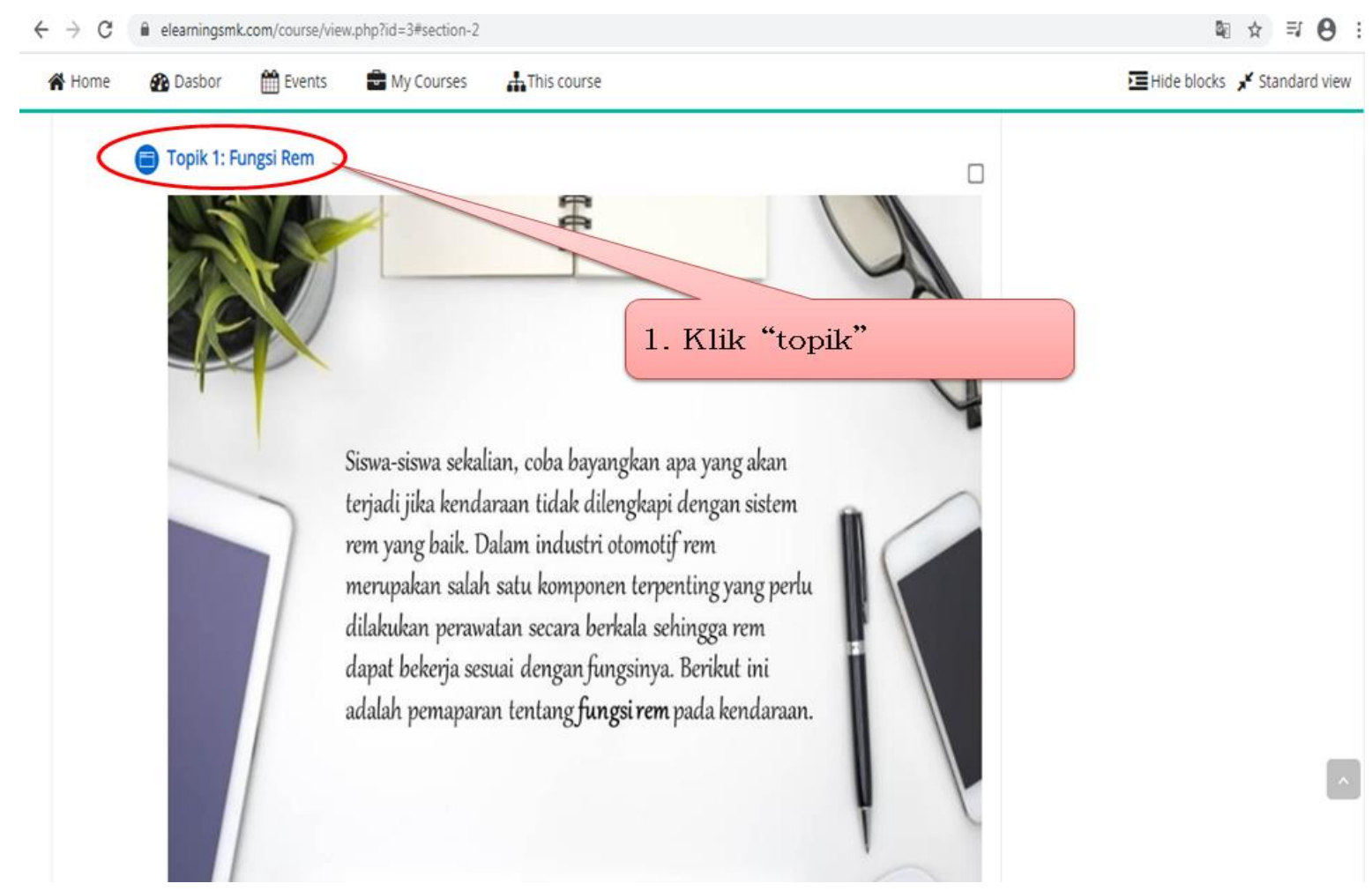

Figure 6. Click "topic"

\section{Conclusion}

The development of blended learning with the model of the flipped classroom in Chassis Maintenance and Light Vehicle Power Transfer for students helps students and teachers in the learning process as a learning strategy in overcoming the problem of lack of face-to-face time in class and at the same time as a source self-directed learning for students. The procedure for developing blended learning uses the ADDIE model integrated with PEDATI at the instructional design stage.

The results of the feasibility analysis from the experts for the development of blended learning in chassis maintenance and light vehicle power transfer subject for second-grade students of Dewantara vocational school are $91.67 \%$ from the material expert with very good qualifications, $80 \%$ from the media expert with good qualifications, and feasible to use with revisions as needed, and $96.47 \%$ from the instructional design expert with very good qualifications, and feasible to use without any revisions. Thus the blended learning is feasible to be used in learning by second-grade students at Dewantara vocational school and is expected to be effective in achieving learning outcomes and efficiency in using limited learning time at school. 


\section{References}

Aeni, N., Prihatin, T., \& Utanto, Y. (2017). Pengembangan Model Blended Learning Berbasis Masalah pada Mata Pelajaran Sistem Komputer. Innovative Journal of $\begin{array}{llll}\text { Curriculum } \text { and } & \text { Educational 84-97. }\end{array}$ https://doi.org/10.15294/ijcet.v6i2.15642

Akkoyunlu, B., \& Soylu, M. Y. (2008). A Study of Student' s Perceptions in a Blended Learning Environment Based on Different Learning Styles. Journal of Educational Technology \& Society, 11(1), 183-193.

Arnold-Garza, S. (2014). The Flipped Classroom Teaching Model and Its Use for Information Literacy Instruction. Communication in Information Literacy, 8(1), 7-22.

Banggur, M. D. V., Situmorang, R., \& Rusmono. (2018). Pengembangan Pembelajaran Berbasis Blended Learning Pada Mata Pelajaran Etimologi Multimedia. Jurnal Teknologi Pendidikan, 20(2), 152-165.

Branch, R. M., \& Dousay, T. A. (2015). Survey of Instructional Development Models (Fifth Edit). Association for Educational Communications and Technology.

Butt, A. (2014). Student Views on the Use of A Flipped Classroom Approach: Evidence from Australia. Business Education \& Accreditation, 6(1), 33-44.

Cole, J. E., \& Kritzer, J. B. (2009). Strategies for Success : Teaching an Online Course. Rural Special Education Quarterly, 28(4), 36-40.

Dabbagh, N., \& Bannan-Ritland, B. (2005). Online Learning: Concepts, Strategies, and Application. Pearson.

Darmawan, D. (2015). Teknologi Pembelajaran. PT. Remaja Rosdakarya.

Daryanto, \& Karim, S. (2017). Pembelajaran ABAD 21. Gava Media.

Estika, W. A. (2017). Pengembanagn Blended Learning dengan Strategi Flipped Classroom pada Mata Pelajaran Desain Multimedia di SMK PGRI Ploso. Jurnal IT-EDU, 2(2), $141-148$.

Fitriyadi, H. (2012). Keterampilan TIK Guru Produktif SMK di Kabupaten Hulu Sungai Utara dan Implementasinya Dalam Pembelajaran. Jurnal Pendidikan Vokasi, 2(2), 213233.

Garrison, D. R., \& Vaughan, N. D. (2017). Blended Learning in Hugher Education Framework, Principles and Giudelines. European Journal of Education Studies, 3(5), 29-40. https://doi.org/10.5281/zenodo.814302

Graham, C. R., Borup, J., Short, C. R., \& Archambault, L. (2019). K-12 Blended Teaching : A Guide to Personalized Learning and Online Integration. Creative Commons CC BY SA.

Husain, C. (2014). Pemanfaatan Teknologi Informasi dan Komunikasi dalam Pembelajaran di SMA Muhammadiyah Tarakan. Jurnal Kebijakan Dan Pengembangan Pendidikan, 2(2), 184-192. 
Kurniawati, R., \& Wardi, H. (2014). Pengembangan Model Pembelajaran Blended Learning pada Mata Pelajaran KKPI Kelas XI di SMK Negeri 2 Purwodadi. Indonesian Journal of Curriculum and Educational Technology Studies, 3(1), 47-55.

Mccarthy, J. (2016). Reflections on a flipped classroom in first year higher education. Issues in Educational Research, 26(2), 332-350.

Miliszewska, I. (2017). Is it fully On or partly Off? The Case of Fully-Online Provision of Transnational Education. Proceedings of the 2017 InSITE Conference, 6.

Milman, N. B. (2012). The Flipped Classroom Strategy: What is it and how can it best be used? Distance Learning, 9(3), 85-88.

Mohanty, A., \& Parida, D. (2016). Exploring the Efficacy \& Suitability of Flipped Classroom Instruction at School Level in India: A Pilot Study. Creative Education, 2016(7), 768776.

Mukarom, Z., \& Rusdiana, A. (2016). Komunikasi dan Teknologi Informasi Pendidikan: Filosifi, Konsep, dan Aplikasi. Pustaka Setia.

Ozdamli, F., \& Asiksoy, G. (2016). Flipped Classroom Approach. World Journal on Educational Technology: Current Issues, 8(2), 98-105. https://doi.org/10.18844/wjet.v8i2.640

Prasetyo, A. A., Putro, S. C., \& Wirawan, I. M. (2016). Kajian Keterlaksanaan Blended Learning pada Program TKJ di SMK. Tekno, 25, 25-32.

Smaldino, S. E., Lowther, D. L., Mims, C., \& Russell, J. D. (2015). Instructional Technology and Media for Learning (Eleventh E). Pearson.

Staker, B. H., \& Horn, M. B. (2012). Classifying $K-12$ Blended Learning. Inno Sight Institute.

Tegeh, I. M., Jampel, I. N., \& Pudjawan, K. (2014). Model Penelitian Pengembangan. Graha Ilmu.

Trilaksono, T., Sasmokob, Tindas, A., Kartika, R., \& Suroso, J. (2018). Does Flipped Classroom Work in Indonesian Schools? Potential and Its Challenges. International Journal of Pure and Applied Mathematics, 120(6), 7749-7762.

Utami, I. G. A. L. P. (2018). The Online Learning of Teacher Profession Education Program (PPG) for In-Service English Teachers: Challenges and Accelerated Learning Factors. Jurnal Pendidikan Indonesia, 7(2), 145-153.

Wallace, A. (2014). Social Learning Platforms and the Flipped Classroom. International Journal of Information and Education Technology, 4(4), 293-296. https://doi.org/10.7763/IJIET.2014.V4.416 